\title{
14 Institutional change in extractive economies
}

\author{
A research agenda from the Andes
}

\author{
Bettina Schorr and Gerardo Damonte
}

\section{Introduction}

The observation that resource-rich states tend to struggle with a whole series of political and economic problems - the curse - has prompted vigorous debates among scholars trying to decipher the causes and consequences of this fatal relationship. Institutions are at the heart of this debate: It is argued that in absence of a strict regulatory framework, the different expressions of the curse will appear. Moreover, the resource curse perpetuates itself by preventing the emergence of functioning regulatory institutions. In this way, this argument points to a vicious cycle that implies an unavoidable fate for the many resourcerich countries in the world characterized by weak institutional capacities, as the Andean countries are.

In contrast to these foundational tenets of the resource curse approach, we find that the Andean region demonstrates that the pathologies of the curse and institutional change towards mitigating it can take place at the same time. Expressions of the curse can be detected throughout the region, from macroeconomic problems to social conflicts and political dysfunctionalities to environmental and health damage. This is even true for the case of Chile, generally considered an outlier among the Andean cursed nations, because of its cautious macroeconomic management and the high quality of its institutions (World Bank, 2019). Some authors even argue the country has managed to overcome the curse (Haslam, 2016; Saylor, 2014). Yet, scholars in this book (Maillet and Carrasco, Rabi and Campos) argue that it depends where you look at: Chile is facing serious environmental and other local problems related to its extractive economy, which can be interpreted as manifestations of the curse. Thus, applying a comprehensive typology of the dimensions of the curse (Orihuela, 2018), the different manifestations can definitely be identified throughout the Andean region.

At the same time, institutions have been established or changed in order to tackle the problems associated with the extractivist development models promoted in the Andes. Against the daunting predictions of the resource curse approach, the different chapters of this volume reveal a wide array of innovations in regulatory and redistributive institutions. These include fiscal reforms 
and social policy innovations, anti-corruption and participatory reforms, as well as environmental regulation. Thus, confirming that important institutional changes to tame the resource curse can occur under the conditions of resource economies characterized by weak state structures is the first important contribution of this volume. This finding is further backed by recent scholarship proclaiming a whole inclusionary turn (Kapiszewski et al., 2021) for Latin America that is diagnosed on the basis of the adoption of many of those political institutions required to mitigate the different expressions of the curse.

By exploring the ways these institutions have emerged and how they perform, the chapters of this volume add further insights to the incipient discussion on institutional change in resource-dependent contexts. In a general perspective, they find that institutional change and performance in the Andean resource economies must be understood as phenomena that are much more complex than pictured by the resource curse literature. Institutional change can be triggered by different actors through a diverse set of pathways and involving different causal mechanisms. By extension, the book underscores that institutions have to be understood as the result of ongoing social processes embedded in specific domestic political and cultural contexts as well as shaped by global dynamics.

In the remainder of this concluding chapter, we lay out a first draft of a research agenda on institutional change and performance in resource-dependent contexts. For this agenda, we distil a series of hypotheses and theoretical implications from the books' chapters that may be valid across different countries and regions. Based on these, we raise a couple of relevant questions for further research. Our nascent research agenda includes six thematic areas: 1) governments and institutional change in resource economies; 2) beyond the government: the role of non-state actors and international organizations; 3 ) the patterns, sequencing, and timing of institutional change; 4) institutional design and implementation; 5) context matters: the national and subnational contexts; and 6) informal institutions in resource governance. These areas are certainly interdependent but focus on different aspects of institutional change and performance under the conditions of resource dependence. We elaborate on each briefly and close with some final remarks.

\section{Governments and institutional change in resource economies}

Governments adopting the types of institutional change capable of easing the resource curse are not only wishful thinking of international organizations and NGOs promoting the good governance of the extractive sector. In the Andean region, governments acting out of their own intrinsic motivation (without domestic or external pressure) have indeed been active promoters of institutional change with the potential of mitigating the resource curse by using their executive powers or by mobilizing their legislative majorities. While the chapters of this book focus on individual institutions, it should not be forgotten 
that in several countries governments also promoted institutional change on the macro level: during the latest commodity boom, Venezuela, Bolivia, and Ecuador wrote and adopted new constitutions which at least on paper significantly reshaped state-society relations in an inclusive way (Kapiszewski et al., 2021; Schilling-Vacaflor \& Nolte, 2012).

It should also be stressed that governments promoting institutional change by using the rents of the resource sector is not a new phenomenon. Historical research into state building in Latin America has repeatedly emphasized that political elites have invested resource rents to strengthen state capacity in order to be able to provide collective goods and promote economic growth and social well-being among their citizens. Such was the case in 19th-century Chile, where domestic elites used the rents stemming from the nitrate boom to build up the public administration of the country and its infrastructure (Kurtz, 2013). As a matter of fact, the Chilean state is as robust as it is today amongst others because of this strategic use of resource rents in the past (Soifer, 2016). Also, in Peru the rents flowing from the guano boom into the states' accounts were used by President Ramón Castilla in the mid-19th century to strengthen state capacity (Kurtz, 2013; Bonilla, 2020). Likewise, Saylor (2014) has showed that commodity booms can act as windows of opportunity for state building when the export sector forms part of the domestic ruling coalition, which he found for the cases of Chile and Argentina.

Certainly, building up a strong state does not necessarily equate to the political will to address all the different dimensions potentially affected by the resource curse. Even in the case of the strong Chilean state, environmental regulation has not been on the governments' agenda and had to be pushed on it from the outside (see later). The point to be stressed here is that both in the distant as well as in the recent past, governments have promoted institutional changes towards the mitigation of the resource curse, reflecting Dietsche's (2007) assertion that political will can make a difference (for institutions). Against this background, one important question to be addressed by future research should target the intrinsic incentives driving governing elites to bring about institutional changes in specific sectors.

In this sense, it has been shown that new regulation concerning the governance of the extractive sector was often motivated by the desire to attract foreign capital requiring a clear legal framework (Bebbington \& Bury, 2013). While redistributive institutions are sometimes viewed as the domain of leftist governments (Campello, 2015; Levitsky \& Roberts, 2011), the new fiscal rules and social policies as studied by Jiménez and Evia (this volume) were introduced in the region regardless of the political color of the sitting governments (Fairfield \& Garay, 2017). Haslam and Heidrich (2018) stress that during the latest boom resource nationalism defined as states' actions to enhance its influence over the extractive sector by the maximization of public revenue, the assertion of strategic state control, and the enhancement of developmental spill-overs from extractive activities could be found anywhere in the region. They differentiate, though, between radical and modest versions of resource nationalism, as found 
in Venezuela and Colombia respectively. Hence, rather than ideological factors, greater profits in the extractive sector combined with electoral incentives stemming from citizens' demands for redistribution seem to have promoted institutional change in these sectors (Fairfield \& Garay, 2017). However, the actual extension of these reforms seems to depend on ideology.

The flip side of exploring the intrinsic incentives for governments to reform would be to identify the sectors where governments resist institutional change. In other words, further research should explore what is persistently missing in terms of institutional change and why. One prime example for such a missing reform can be found in the fiscal sector. While minor reforms regarding taxing citizens have been introduced for instance in Chile and Colombia, thorough progressive tax reforms are notoriously absent in the whole region (Atria et al., 2018). This absence persists notwithstanding the mantra of experts in the field who emphasize that progressive tax systems would be essential to tackle the majority of the problems associated with the resource curse. In particular, a progressive tax system would stabilize domestic resources and reduce the economic dependence from the volatile global commodity markets. Moreover, it is argued that state-society relations based on progressive taxes - the fiscal pact-promote transparency and increase the accountability of public officials.

Yet, the lack of a fiscal contract that some authors argue is the main problem of resource-dependent economies (Moore, 2004; Karl, 2007) has been perpetuated through the latest boom cycle in the region. In several cases, scholars have identified elite lobbyism as one factor avoiding tax reforms in the region (Fairfield, 2015; Bogliaccini \& Luna, 2016.). As shall be discussed later, this has serious consequences for the sustainability of some of the institutional reforms that did take place.

In other occasions, government may have the intention to change but need to impose it against reluctant rent-seekers in the legislature or other private powerful actors. The first may be of particularly importance for the Latin American presidential systems, in which political preferences of presidents and legislatures can differ sharply. To overcome legislative or elite resistance, strategic coalitions with civil society organizations and international organizations may be helpful (Schorr, this volume). Regarding elite resistance, research has found that it is less pronounced in boom times (Campello, 2015), when business elites are integrated into cohesive networks (Cárdenas, 2020) and when elites actually are aware of social problems they command the power to redress (Reis \& Moore, 2005).

\section{Beyond the government: the role of non-state actors and international organizations}

Institutional change is not always the product of the genuine political will of governments. Reflecting the argument that under the adverse conditions of resource economies institutional change is at best difficult, this book shows that in many instances of change, governments had to be pressured to adopt 
new rules. This highlights the importance of non-state actors and international organizations in promoting institutional change in resource economies and reveals the limits of the state as a driver for institutional change. The state rather constitutes an arena of contention where different actors strive for imposing their own institutional agendas. Thus, just as examining intrinsic motivations of governments is important, further research may explore under which conditions non-state and international actors can promote institutional change, in which sectors and how.

As showed in this book, in some cases the pressure for change derived from social mobilizations and protests, both nationally as well as regionally and locally. This has been found for the adoption of new environmental rules by the San Juan provincial government in Argentina, new policies for citizen participation and political transparency in Chile and Peru, and changes in the formalization norms for small-scale mining in Madre de Dios, Peru (see the chapters by Godfrid, Schorr and Damonte). As Bornschlegl and Cisneros, Evia, and Flemmer (this volume) note for the cases of Ecuador, Bolivia, and Peru respectively, many institutional changes with redistributive or regulatory character carried out during the latest boom represented long-standing demands of different mobilized social groups, such as unions, peasant organizations, or indigenous groups.

In other cases, international organizations (e.g. OECD, ILO, World Bank) and donor cooperation put pressure on governments by tying institutional change to material (credits, funds etc.) or symbolic rewards, for instance in the case of the environmental systems in Chile and Peru (chapters by Maillet and Carrasco; Rabi and Campos and Paredes and Figueroa). By the same token, Flemmer (this volume) highlights the importance of national and transnational advocacy networks in pushing the Peruvian government to regulate the ILO 169 agreement regarding indigenous consultation by enacting a national consultation law. As shall be discussed in more detail in the next section, domestic mobilization and external pressure often converged to push governments towards institutional change.

The involvement of national and transnational non-state actors and international organizations in processes of institutional change has several implications: In a practical sense, it reveals the leverage of international actors that holds the potential of supporting or empowering domestic reform coalitions, not just governments. On the other hand, institutional change propagated by these actors may provoke problems associated with institutional isomorphism: They may constitute a no fit condition and be ineffective in the respective local context (we elaborate on this point later). Further research should identify the conditions under which local mobilizations and international leverages interact to produce effective institutional change.

As mentioned in our introduction, business actors may also influence institutional change and performance in resource-dependent contexts. So far, research on how business can affect institutions often focusses on business elites as promoters of extractive institutions that ensure their privileged access to resources (i.a. Madariaga et al., 2021; Durand, 2016; Bull \& Aguilar-Støen, 2015). However, 
as stated earlier, under certain conditions business actors have also been found to support inclusive institutions. Haslam (2016) and Saylor (2014) mention the important role of business actors in promoting efficient regulatory institutions, thereby preventing the states from succumbing to the curse.

Also, transnational initiatives, such as the EITI or the International Council on Mining and Metals (ICMM), involve companies as actors in processes of institutional change in the member states. Regarding the latter, authors discuss whether they have to be understood as a corporate version of window dressing institutions or whether they have a real effect on constraining corporate and political behavior detrimental to the good of society. This point about how to differentiate between self-serving expediency and positive influence should be addressed in more detail in future research.

Another incipient stream of research explores the consequences of corporate behavior in host communities, where they carry out their projects. In particular, it has been argued that companies by means of their CSR programs have a strong impact on the daily routines of communities, i.e. how these communities organize their economies and social life. It has also been argued that CSR programs generate unexpected and undesired institutional consequences: Where corporate services substitute for public service delivery (like access to water, public infrastructure etc., as for example in Peru), in the longer run this may interrupt or slow down processes of institutional strengthening on part of the state by eroding citizens' demands towards the state (Bebbington, 2010). Future research may confirm empirically this relationship between corporate activities on the local level and institutional defects on the national level and identify the expressions it may take.

\section{The patterns, sequencing, and timing of institutional change}

Processes of institutional change in resource-dependent contexts may follow specific patterns and timings. The chapters of this book indicate the significance of different patterns of involvement of state and non-state actors in different policy sectors.

As mentioned earlier, governments were promotors of sectoral regulation and of institutions that capture a higher share of the sectors' rents, increase redistribution, or provide social assistance. In contrast, environmental institutions have not been placed first on governments' agendas, which may confirm the resource curse literatures' argument of politicians being myopic and refraining from putting hard constraints on the sector. The empirical cases analyzed in this book may indicate that or international organizations with leverage capacity or massive domestic social movements (partly supported by transnational advocacy) or a mix of both are key in promoting institutional change in the environmental sector. Certainly, this assertion is not meant to be exclusive. International pressure was also present in other sectors (e.g. the transparency reforms in Chile prior to its acceptance to the OECD) and massive regionally based social 
movements have demanded fiscal decentralization in Peru. Occasionally, governments have adopted and implemented environmental programs as shown in Bornschlegl's study on integral reparation in Ecuador. Notwithstanding these single cases, empirical evidence of this book may lead us to hypothesize a certain bias towards the environmental sector that reflects the sectoral preferences of international agencies as well as social values (environmental protection) and local grievances (contamination) on part of domestic non-state actors. Future research may explore if this tendency constitutes a robust relationship and, if so, find the underlying causes. More especially, it would be important to find and explore cases of governments adopting institutions for environmental protection without external pressure (i.e. by intrinsic motivation).

The chapters of this book also allow us to address hypotheses with regard to the timing and sequencing of institutional change under the adverse conditions of resource economies. Two patterns can be discerned. The first connects institutional change promoted by international actors to domestic challengers and may imply that a sequence is at work. In cases where international pressure established a formal framework against reluctant governments, social pressure and protest may be necessary to activate or enhance its transformatory effect. The first was the case with the translation of the international convention of prior consultation into actual Peruvian law in the context of the Bagua conflict (Flemmer, this volume). The second can be found in case of environmental legislation in San Juan, Argentina, which was first introduced on the basis of international factors (the Rio Convention and Japanese donor cooperation) and then further refined to the rhythm of social mobilizations. For this reason, and drawing on a concept coined by Dargent and Urteaga (2016), Godfrid (this volume) speaks of a type of reactive change that is only adopted when social pressure on governments is so high as to make it unavoidable.

This statement contrasts with the problems that has been mentioned related to institutional isomorphism. In the case of the Peruvian OEFA, Paredes and Figueroa (this volume) argue that the externally promoted institution could not count on social support, which contributed to its weakness. On the other hand, institutional change imposed against the resistance of states by domestic challengers may be more sustainable when international actors use their leverage to push for effective implementation of these institutions (we return to this point later).

Second, the opportunities for institutional change may also vary along the boom-post-boom divide depending on the presence or absence of economic windfalls. Some institutional changes, such as the increase of the states' share of the extractive sectors' rents, may be easier to achieve during boom times when the overall profits are high. As mentioned, scholars have argued that business elites are more willing to support or at least not obstruct state interventions into the economy in times of fat cows when a higher redistribution is not perceived as a loss (Campello, 2015).

Other institutional changes might be easier to adopt in times of economic downturn, when the incentives set by the exuberant profits of the sector have 
receded. Transparency reforms may be a case in point. As Moreno shows (this volume), across the Andean region social perception of corruption has increased significantly only after the latest commodity boom has ended. Likewise, it was only towards the end of the boom that many countries saw the revelation of mega corruption scandals and social disapproval increased until opening up a window of opportunity for transparency reformers (Schorr, this volume). The causal mechanisms underlying this finding should be explored in more detail. They might mirror the results from studies conducted in other world regions that reveal people tend to ignore some of the fallacies of resource economies (such as authoritarianism and corruption), whilst the general perception is that everybody wins (Jones Luong \& Weinthal, 2009 for the post-Soviet republics). Ignoring the fallacies associated with resource dependence would then be an important barrier to institutional change, and more information of potential pitfalls could act as a redress.

Fiscal reforms may also be a case in point. Jiménez (this volume) raises the question of whether the post-boom period could be a good moment to alter fiscal redistribution schemes adopted during the boom period that significantly contribute to territorial inequalities in the region. In a variation of the argument regarding the reduction of elite resistance against redistributive measures during boom times, he argues that the post-boom could constitute a window of opportunity. Since it can be assumed that the losses a further reform of the fiscal system would generate would be lower for the affected subnational jurisdictions in times of economic bust, also their resistance might be lower. As an implication, times of thin cows might in some sectors constitute better moments for promoting institutional change.

Altogether, these different trajectories, patterns, and sequences lead us to better understand the diachronic feature of institutional change. Institutional change is not a linear process that unfolds following a pre-designed manual or guideline; it is rather a social process whose trajectory depends heavily on the social conditions and power balances among state and non-state actors. Suitable social conditions and favorable power balances may create opportunities to overcome the maladies associated with the resource curse so that social actors are able to push forward institutional changes.

\section{Institutional design and implementation}

While this book confirms that institutional change took place rather frequently, almost all chapters reveal deficiencies in at least one of two interrelated areas: institutional design and implementation. The authors of several chapters argue that institutions lost their innovative elements and objectives during implementation, and even ended up reproducing the negative social situations and behaviors that they were intended to change. The chapters underscore, thus, that full-fledged institutional change towards mitigating the resource curse should be grasped as a two-step process in which the emergence, adoption, or sound design of new institutions does not in itself assure effective implementation. 
Scholars and practitioners alike should pay attention to these complexities and focus not only on the adoption of curse-preventing institutions in resource economies, but analyze in much more detail the way they are designed and the consequences of their design for the achievement of their statutory goals as well as the constraints operating upon their effective implementation.

Regarding design, several chapters in this book show that new institutions have been adopted which for their name and statutory goals would seem to be able to constrain behavior conducive to the manifestations of the resource curse. At times, the establishment of, for example, new environmental ministries have elicited approval and praise on the part of international actors and donor cooperation. However, when a closer look at these institutions is taken, it becomes clear that they have been designed by powerholders in such a way that their consequences are ultimately minimal. Thus, these institutions seem to represent window dressing institutions formally adopted to please external actors (such as international organizations) or to ease internal pressures (such as social mobilizations). Maybe a renewed version of the resource curse should not focus on the presence or absence of regulatory institutions, but on the way they are set up and function (or do not function). The authors of this book have described the lack of impact in the face of factual formal institutional change by using different concepts: Flemmer detects unwanted change in the case of prior consultation in Peru that has been legally downsized in the national legal framework. Maillet and Carrasco find apparent change in the Chilean extractive sector. These authors also argue that change is limited to the environmental subsector and has almost no constraining effect on the dominant extractive regime as demonstrated in the persistent increase of both the number of projects as well as the number of social conflicts these provoke (a similar argument is presented by Paredes and Figueroa for the case of the Environmental Ministry in Peru). Maillet and Carrasco (this volume) also state that business has actively lobbied for specific institutional designs, in order to evade actual constraints. In Peru (Paredes and Figueroa, this volume; Durand, 2016) and Ecuador (Cisneros, this volume) as well, mining industries have been found to influence the design of the sectoral regulation (environmental and other) to cushion its effects on their interests. Likewise, Rabi and Campos (this volume) argue that business-friendly political forces in the Chilean Congress have designed the Environmental Courts in a way that intentionally reduces their scope of action and, with it, their potential to constrain ecologically harmful activities.

Defects by design are not always the product of a strategic political calculus, but may also represent unanticipated or undesired side effects. The chapters by Jiménez and Evia (this volume) make this point by laying out the consequences in terms of territorial inequalities and financial unsustainability, respectively. These two chapters also underscore another aspect important for scholars and practitioners alike: the interdependence of policy sectors. This aspect has been addressed by the institutional analysis literature as the institutional complexity of current societies (Campbell, 2010), in which changes in one institution can affect other institutions. Fiscal reforms and social policy reforms are a case in 
point: When the fiscal system fails to provide public resources in a sustainable way, social policy instruments may lose their transformatory potential once the boom and its windfalls vanish. In other words, it is important to address the different policy sectors required for mitigating or avoiding the curse, in a comprehensive way and simultaneously. Future research should address these interdependencies in order to obtain a better understanding of the workings of institutional complexities in resource economies.

Another important factor constraining the implementation of new institutions is the lack of money that is directly related to the dynamics of extractive economies. Several authors in this volume point out to the problem of lack of resources which arises from the cyclicity and volatility of global commodity markets (see also Vos, 2012; Campello \& Zucco, 2021). Once the boom recedes, the money needed to implement institutional changes for instance in the environmental sector (Bornschlegl, this volume) or in the social or public sectors (Evia and Jiménez, this volume) will run short. Even the attempt to diversify the extractive sector in Ecuador has been curbed when the rents from the oil sector decreased (Cisneros, this volume). At the same time, as mentioned before, it may be that precisely these moments of economic downturn can act as windows of opportunities for specific institutional changes, even with fewer financial resources.

Other factors found in the chapters of this book to be affecting institutional implementation are unrelated to the dynamics of the resource economy. These include for instance the lack of bureaucratic or professional capacity (Paredes and Figueroa, this volume), the lack of trust in the state (Bornschlegl, this volume), as well as the lack of executive power of public agencies to enforce institutions across the national territory (Bornschlegl, Damonte, this volume).

The latter two factors underscore that institutional implementation-like institutional emergence - is basically a function of power, and that social agency is fundamental for understanding institutional implementation. Particularly, power and cultural dynamics shape institutional implementation in contexts where the state is not the only actor holding power and may not even be the most powerful one. Throughout the chapters in this volume, we learn about how transnational corporations and local elites have reduced the new institutions' transformative elements, for the sake of private profits. On the other hand, non-hegemonic social actors have been shown to shape the implementation of new public policies through resistance and mobilization.

We finish this section on institutional design and implementation with two reflections. The first concerns the problems related to institutional isomorphism. Since in resource economies institutional change may depend to a higher degree on international pressure (at least in specific sectors, as discussed before), a research agenda focusing on the effective implementation of institutions in resource economies should be attentive to the problems of no fit: governments may import uncritically institutional frameworks developed under different conditions that do not fit their own national, regional, or local social dynamics and are, hence, prone to failure. Isomorphism and territorial no fit 
may affect institutional implementation, as shown in the chapters by Paredes and Figueroa and by Damonte (this volume). In both cases, imported institutions (the Peruvian Environmental Ministry as a case of global isomorphism and the state formalization plans imposed by the Peruvian central government to regulate mining activities in the Peruvian Amazonia) were seen as alien by the people supposed to comply with them (the rule takers, in the words of Streeck and Thelen (2005)). As a consequence, they refused to do so. Future research should focus on the mechanisms that may allow to foster the adjustment and grounding of national and international policies to specific contexts and territories so that they can work effectively.

Second, what institutions actually accomplish and the effects they have do not only depend on design and enforcement. As Rabi and Campos (this volume) argue, the effects of an institution are also a function of how they are used by social actors, mirroring (without mentioning) the argument of institutional analysts regarding the discretionary potential that all institutions (to some extent) have. The authors show that the Environmental Courts in Chile do not necessarily act as protection shields for the environment. They are more often used by business actors precisely to dispute state decisions grounded in environmental concerns. And those actors tend to be successful. Most decisions of these courts benefit project holders and not the local communities complaining over environmental damage. Thus, the actual use of institutions and how this use might be related to the dynamics of resource economies should also be of concern to a research agenda on institutional dynamics under the conditions of resource dependence.

\section{Context matters: the national and subnational levels}

We stated at the beginning of this chapter that processes of institutional change need to be understood and analyzed as ongoing processes, embedded in specific local, national, and global contexts. In fact, the chapters of this volume show that specific contexts matter greatly for explaining and exploring the opportunities for institutional change and effective implementation.

The universe of potential contextual factors that may condition institutional dynamics in resource economies is wide and includes amongst others specific state-society relations, political settlements, culture and economic contexts, and the quality of democratic institutions. We give an example for each: Regarding state-society relations, the alliance between informal miners and the government in Bolivia structured the governance of the informal gold mining sector in Bolivia in a way that prevents the effective implementation of regulatory institutions (Amengual \& Dargent, 2020). Cultural factors matter when the presence (Bolivia, Chile) or absence (Ecuador) of the idea that countries are and have always been "mining countries" influences if the mining sector is more or less constrained (Koch \& Perreault, 2019). Specific elite settlements may allow for a greater or lesser regulation of the extractive sector and the redistribution of its rents. For example, the presence of leftist governments may promote a greater 
redistribution of the sector's gains in the form of radical resource nationalism (Haslam \& Heidrich, 2018), and the orientation of the national business elite can make a difference when it comes to institutional arrangements intended to avoid the curse and take the route towards the developmental state (Haslam, 2016). The national economic context may matter when different extractive sectors coexist in one country. As Cisneros (this volume) shows for the case of Ecuador, the historical dominance of the oil sector has significantly hindered the effective regulation of the mining sector.

Even the way societies perceive the different expressions of the curse can matter and be consequential for institutional demands and potentially affect processes of institutional change. Moreno (this volume) discusses that the perception of corruption has no impact whatsoever on citizens' support for democracy in Bolivia and Peru (but in other countries of the Andean region). He hypothesizes that this results from the fact that societies in these two Andean countries seem to be more impervious to the existence of corruption. Since they are more accustomed to its presence, corruption might be less likely to affect the evaluation they make of the political system.

Finally, the opportunities for institutional change depend on the quality of democracy in place. While the literature has stressed the good governance of the sector and related areas as the remedy to the resource curse, it seems obvious that it only can be governed in a good way when the very political fundament is of a good quality. This includes a functional system of democratic representation, the presence of institutional checks and balances, and state agencies insulated from undue political influence capable of implementing rules of good governance. As shown by Schorr (this volume), if these conditions are lacking, reforms to tame the expressions of the resource curse may be difficult and come at high social, political, and even economic costs (as in the case of transparency reforms in Peru).

Context does not only matter nationally, but also on the subnational level where the local conditions may quite vary from those of the capitals hosting central governments and legislatures. In resource economies, particularly those territorial units where the resources are being extracted may be able to significantly shape how institutions are implemented or establish institutions that may mitigate or instigate the local expressions of the curse. In particular, the way in which subnational territories are linked to national and international political dynamics may affect how institutional change unfolds at the subnational level. As we have seen, national institutional dynamics are often subject to the effects of external actors; the same applies for subnational territories, such as the province of San Juan in Argentina, where external actors have played a greater role than the national government in setting up the environmental institutional frameworks in a federal country (Godfrid, this volume).

In a variation of the subnational resource curse, scholars should explore processes of institutional change and implementation in subnational units, extrapolating the conditions and factors that promote or prevent institutional change and effective implementation. 
In sum, different national or local contexts may allow for different institutional changes in different sectors at different moments. Exploring how these contexts shape the opportunities of institutional change aiming at the prevention or mitigation of the resource curse will spur our understanding of when and which change may be possible under the potentially adverse conditions of resource economies.

\section{Informal institutions in resource governance}

The resource curse approach has treated informal institutions as causes for the curse. In particularly, rent-seeking, corruption, clientelism, and patrimonialism have been stressed as informal institutions afflicting resource-dependent countries.

However, other scholarship has carved out the importance of informal institutions for understanding resource governance. It has been shown that informal institutions are present in many governance schemes and are not circumscribed to tradition and customary law (Farinós Dasí, 2008; Larson \& Soto, 2008; Pahl-Wostl, 2009). Distrust in the state and the institutions it enforces may also lead to the emergence of new informal practices. Often, formal and informal institutions interact, producing hybrid institutional frameworks (Sindzingre, 2006; Sardan, 2013; Damonte, 2021). Thus, the role of informal institutions in resource governance and how they prevent or promote the different expressions of the curse point strongly to another element that should be on the research agenda on institutional change in resource economies.

In this book, the chapter by Damonte reveals how agribusiness shaped the governance of their respective extractive regimes by imposing a series of informal practices that favor them. Moreover, the author shows how long-standing state territorial policies and current political dynamics shape the implementation of the formalization processes in Madre de Dios, creating what the author defines as hybrid institutional entanglements.

The hybrid character of governance schemes has been studied from various perspectives. Political scientists have explored several emerging hybrid modes of governance across the state-market community divisions in the environmental sector. These studies explore how state and non-state actors configure networks for co-management, public-private partnerships, and social-private partnerships in governing the environment and natural resources (Lemos \& Agrawal, 2006). From an anthropological perspective, studies have also stressed the formalinformal character of some hybrid modes of governance (Sindzingre, 2006; Sardan, 2013).

In the latter perspective, processes of institutional hybridization tend to take place when states command limited power over the territories they are supposed to govern and people lack trust in public institutions (Damonte, 2018, 2021). In cycles of extractive territorial expansion, new formal and informal rules surged through state impositions, institutionalization of local practices, and local appropriation and reinterpretation of state or corporate institutional initiatives 
in the context of constant state and corporative political negotiation with local powers to legitimate their presence and extractive rights.

\section{Final remarks}

This chapter laid out an agenda for future research on institutional change and performance in resource economies. After decades of focusing on the maladies that resource-dependent states tend to suffer, this research agenda revolves around the remedies to the curse: how institutions can be built and perform effectively, notwithstanding the potentially adverse dynamics resulting from resource dependency. On a general level, the book and the agenda developed in it propose that institutional changes ought to be analyzed as grounded in social processes. There may certainly be conditions that prevent institutional innovations in resourcerich regions, countries, and territories, but actual institutional developments will ultimately depend on the way social actors address the situation. Thus, it is fundamental to consider both conditions and contextual factors as well as social agency to fully understand institutional change as a cross-sectoral process.

In particular, the research agenda we have developed includes six thematic areas that focus on different aspects of institutional change and performance under the conditions of resource dependence. This agenda is meant as a first step; future research will certainly unveil other important aspects to be studied and analyzed.

One last word of caution is called for. The concept of the resource curse has been criticized for being stretched and often used synonymously with all sorts of failed development trajectories. In fact, in a region like the Andes, many problems affecting institution-building and performance cannot be traced back directly just to their resource dependency. Some are separate problems caused by other factors, and, indeed, many of them represent long-standing, deeper structural problems. These structural factors are similar throughout the region - as is the long-standing dependence on primary exports. They include limited state capacities (with the exception of Chile) and multidimensional inequalities that compromise significant power and knowledge asymmetries among social groups (Jelin et al., 2018). More recent developments such as the dramatically unequal effects of the global Covid-19 pandemic will strongly shape the possibilities for institutional change and performance in the region as well. In fact, many of these factors also operate in other low-income countries that do not possess vast natural resources to extract and export. Thus, research on the opportunities of institutional change must cautiously distinguish if these factors are operating and, if so, how they may reinforce effects produced by resource dependency.

The chapters in this volume focused on the latest boom period and the first years after the end of this boom in commodity prices. In the meantime, since the end of 2020, global commodity markets have begun an upswing, and some analysts, such as the investment bank Goldman Sachs, find signs that a new postpandemic boom cycle is beginning (Els, 2021). Without any doubt, such a new 
boom period would-again-significantly affect institutional arrangements and performance in the countries of the Andean arch. There will be plenty to study. Our research agenda contributes to explore the field and advance our understanding of inclusive and regulatory institutional change and performance in resource-dependent states.

\section{References}

Amengual, M., \& Dargent, E. (2020). The social determinants of enforcement. In D. M. Brinks, S. Levitsky, \& M. V. Murillo (Eds.), The politics of institutional weakness in Latin America (pp. 161-182). Cambridge University Press. https://doi.org/10.1017/9781108776608.007

Atria, J., Groll, C. L., \& Valdés Valencia, M. F. (Eds.). (2018). Rethinking taxation in Latin America: Reform and challenges in times of uncertainty. Palgrave Macmillan.

Bebbington, A. (2010). Extractive industries and stunted states: Conflict, responsibility and institutional change in the Andes. In K. Ravi Raman \& R. D. Lipschutz (Eds.), Corporate social responsibility: Comparative critiques (pp. 97-115). Palgrave Macmillan.

Bebbington, A., \& Bury, J. (2013). Subterranean struggles: New dynamics of mining, oil, and gas in Latin America. University of Texas Press.

Bogliaccini, J. A., \& Luna, J. P. (2016). Deflecting my burden, hindering redistribution: How elites influence tax legislation in Latin America. WIDER Working Paper 2016/92. UNUWIDER. https://doi.org/10.35188/UNU-WIDER/2016/135-2

Bonilla, H. (2020). Guano y burguesía en el Perú. IEP.

Bull, B., \& Aguilar-Støen, M. (Eds.). (2015). Environmental politics in Latin America: Elite dynamics, the left tide and sustainable development. Routledge.

Campbell, J. L. (2010). Institutional reproduction and change. In G. Morgan, J. L. Campbell, C. Crouch, O. K. Pedersen, \& R. Whitley (Eds.), The Oxford handbook of comparative institutional analysis. Oxford University Press.

Campello, D. (2015). The politics of market discipline in Latin America: Globalization and democracy. Cambridge University Press. https://doi.org/10.1017/CBO9781139599993

Campello, D., \& Zucco, C. (2021). The volatility curse: Exogenous shocks and representation in resource-rich democracies. Cambridge University Press.

Cárdenas, J. (2020). Exploring the relationship between business elite networks and redistributive social policies in Latin American countries. Sustainability, 12(1), 13. https://doi. org/10.3390/su12010013

Damonte, G. (2018). Mining formalization at the margins of the state: Small-scale miners and state governance in the Peruvian Amazon. Development and Change, 49(5), 1314-1335. https://doi.org/10.1111/dech.12414

Damonte, G. (2021). Limited state governance and institutional hybridization in alluvial ASM in Peru. Resources Policy, 72, 102118. https://doi.org/10.1016/j.resourpol.2021.102118

Dargent, E., \& Urteaga, M. (2016). Respuesta estatal por presiones externas: Los determinantes del fortalecimiento estatal frente al boom del oro en el Perú (2004-2015). Revista de Ciencia Politica, 36(3), 655-677. https://doi.org/10.4067/S0718-090X2016000300003

Dietsche, E. (2007). Why the quality of institutions is not a cure for the 'resource curse'. The Journal of Energy and Development, 32(2), 262-282. www.jstor.org/stable/24813112

Durand, F. (2016). Cuando el poder extractivo captura el Estado: Lobbies, puertas giratorias y paquetazo ambiental en Perú. Oxfam.

Els, F. (2021, June 2). 120 year chart shows copper price supercycle only starting. Miningdotcom. www.mining.com/120-year-chart-shows-copper-price-supercycle-only-starting/ 
Fairfield, T. (2015). Private wealth and public revenue: Business power and tax politics in Latin America. Cambridge University Press.

Fairfield, T., \& Garay, C. (2017). Redistribution under the right in Latin America: Electoral competition and organized actors in policymaking. Comparative Political Studies, 50(14), 1871-1906. https://doi.org/10.1177/0010414017695331

Farinós Dasí, J. (2008). Gobernanza territorial para el desarrollo sostenible: Estado de la cuestión y agenda. Boletín De La A.G.E, 46, 11-32.

Haslam, P. (2016). Overcoming the resource curse: Reform and the rentier state in Chile and Argentina, 1973-2000. Development and Change, 47(5), 1146-1170. https://doi. org/10.1111/dech.12259

Haslam, P., \& Heidrich, P. (2018). The political economy of natural resources and development: From neoliberalism to resource nationalism. Routledge. http://gbv.eblib.com/patron/FullRecord. aspx?p $=4391725$

Jelin, E., Motta, R., \& Costa, S. (Eds.). (2018). Global entangled inequalities: Conceptual debates and evidence from Latin America. Routledge.

Jones Luong, P., \& Weinthal, E. (2009). Oil is not a curse: Ownership structure and institutions in Soviet successor states. Cambridge University Press. http://site.ebrary.com/lib/academiccompletetitles/home.action

Kapiszewski, D., Levitsky, S., \& Yashar, D. J. (Eds.). (2021). The inclusionary turn in Latin American democracies. Cambridge University Press. https://doi.org/10.1017/9781108895835

Karl, T. L. (2007). Ensuring fairness: The case for a transparent fiscal social contract. In M. Humphreys, J. Sachs, \& J. E. Stiglitz (Eds.), Initiative for policy dialogue at Columbia. Escaping the resource curse. Columbia University Press.

Koch, N., \& Perreault, T. (2019). Resource nationalism. Progress in Human Geography, 43(4), 611-631. https://doi.org/10.1177/0309132518781497

Kurtz, M. J. (2013). Latin American state-building in comparative perspective. Cambridge University Press. https://doi.org/10.1017/CBO9781139019668

Larson, A. M., \& Soto, F. (2008). Decentralization of natural resource governance regimes. Annual Review of Environment and Resources, 33(1), 213-239. https://doi.org/10.1146/ annurev.environ.33.020607.095522

Lemos, M. C., \& Agrawal, A. (2006). Environmental governance. Annual Review of Environment and Resources, 31(1), 297-325. https://doi.org/10.1146/annurev. energy.31.042605.135621

Levitsky, S., \& Roberts, K. M. (Eds.). (2011). The resurgence of the Latin American left. Johns Hopkins University Press. https://doi.org/10.1353/book.1866

Madariaga, A., Maillet, A., \& Rozas, J. (2021). Multilevel business power in environmental politics: The avocado boom and water scarcity in Chile. Environmental Politics, 8(1), 1-22. https://doi.org/10.1080/09644016.2021.1892981

Moore, M. (2004). Revenues, state formation, and the quality of governance in developing countries. International Political Science Review, 25(3), 297-319. https://doi. org/10.1177/0192512104043018

Orihuela, J. C. (2018). Institutions and place: Bringing context back into the study of the resource curse. Journal of Institutional Economics, 14(1), 157-180. https://doi.org/10.1017/ S1744137417000236

Pahl-Wostl, C. (2009). A conceptual framework for analysing adaptive capacity and multilevel learning processes in resource governance regimes. Global Environmental Change, 19(3), 354-365. https://doi.org/10.1016/j.gloenvcha.2009.06.001

Reis, E., \& Moore, M. (Eds.). (2005). Elite perceptions of poverty and inequality. Zed Books. 
Sardan, J.-P. O. de (2013). Embeddedness and informal norms: Institutionalisms and anthropology. Critique of Anthropology, 33(3), 280-299. https://doi.org/10.1177/0308275X13490307

Saylor, R. (2014). State building in boom times: Commodities and coalitions in Latin America and Africa. Oxford University Press.

Schilling-Vacaflor, A., \& Nolte, D. (2012). New constitutionalism in Latin America: Promises and practices. Routledge.

Sindzingre, A. (2006). The relevance of the concepts of formality and informality: A theoretical appraisal. In B. Guha-Khasnobis, R. Kanbur, \& E. Ostrom (Eds.), Linking the formal and informal Economy. Oxford University Press.

Soifer, H. D. (2016). The development of state capacity. In O. Fioretos, T. G. Falleti, \& A. Sheingate (Eds.), The Oxford handbook of historical institutionalism (pp. 182-191). Oxford University Press.

Streeck, W., \& Thelen, K. A. (2005). Institutional change in advanced political economies. In W. Streeck \& K. A. Thelen (Eds.), Beyond continuity: Institutional change in advanced political economies (pp. 1-39). Oxford University Press.

Vos, R. (2012). Economic insecurity and development in Latin America and the Caribbean. In J. A. Ocampo \& J. Ros (Eds.), The Oxford handbook of Latin American economics. Oxford University Press.

World Bank. (2019). Training for reform: Region profile of Latin America and Caribbean (LAC). World Bank. www.doingbusiness.org/content/dam/doingBusiness/media/Profiles/ Regional/DB2019/LAC.pdf 